\title{
Motivasi Rumah Tangga dalam Usaha Budidaya Ayam KUB di Kabupaten Sigi Propinsi Sulawesi Tengah
}

\author{
Arif Cahyono $^{1 *}$, Pujo Haryono ${ }^{1}$, Fery Fachrudin Munier ${ }^{1}$ \\ ${ }^{1}$ Balai Pengkajian Teknologi Pertanian Sulawesi tengah \\ *Corresponding author: arif.sdm@gmail.com
}

\begin{abstract}
Abstrak
Program BEKERJA merupakan upaya Kementan untuk mengentaskan kemiskinan di tanah air berbasis pertanian dengan tiga tahapan, jangka pendek, menengah, dan panjang. Pada tahun 2018 saat ini Kementan menargetkan program BEKERJA dapat dilaksanakan di 10 provinsi, 776 desa dan 200.000 Rumah Tangga Miskin (RTM). Ayam Kampung Unggul Balitbangtan atau biasa dikenal dengan Ayam KUB merupakan salah satu produk unggulan di sektor peternakan yang dihasilkan oleh Badan Penelitian dan Pengembangan Pertanian (Balitbangtan). Keunggulan Ayam KUB dibandingkan dengan ayam kampung pada umumnya adalah pertumbuhannya relatif lebih cepat, pada umur 70 hari ayam KUB mampu mencapai bobot 800-1200 gr. Keunggulan lain dari ayam KUB adalah produksi telur di atas rata-rata yakni dalam satu tahun dapat memproduksi telur 160-180 butir. Karena keunggulannya inilah ayam KUB mulai diperkenalkan di daerah-daerah yang memiliki potensi pengembangan ayam kampung di Indonesia, termasuk di Sulawesi Tengah. Pada tahun 2019 ini Balai Pengkajian Teknologi Pertanian (BPTP) Sulawesi Tengah melakukan diseminasi produk Balitbangtan ini melalui program pengembangan ayam KUB pada skala rumah tangga ke lima desa sebanyak 100 rumah tangga sebagai pelaksana utama pengembangan ayam KUB. Motivasi rumah tangga sebagai pelaksana kegiatan di sini diartikan sebagai kondisi yang mendorong untuk melakukan tindakan, yaitu mengembangkan usaha budidaya ayam KUB dengan tujuan tertentu, Untuk mengetahui motivasi rumah tangga terhadap budidaya ayam KUB di Sigi maka dilakukan kajian ini. Analisis data dilakukan melalui pendekatan isi dan kedalaman dalam menterjemahkan suatu fenomena sosial dengan berbagai metode analisis; metode deskriptif digunakan untuk menggambarkan kondisi ekonomi dan sosial rumah tangga; karakteristik Peternak. Analisis data tentang motivasi peternak terhadap budidaya ayam KUB dengan menggunakan skala Likert. (Rensis likert dalam hermawan, 2015). Hasil skala Likert yang valid dijumlah untuk masingmasing responden, kemudian dicari reratanya sebagai skor variabel Pengetahuan, Sikap dan Motivasi. Secara keseluruhan dapat disimpulkan bahwa tingkat motivasi rumah tangga dalam usaha mengembangkan usaha budidaya ayam KUB 68\% sangat ingin dan $32 \%$ Ingin. Kondisi ekonomi dan sosial menjadi latar belakang motivasi rumah tangga, sedangkan teknologi budidaya tidak berpengaruh nyata. Hasil kajian ini diharapkan dapat direkomendasikan penyebarluasan inovasi ayam KUB serta peningkatan motivasi serta perekonomian masyarakat di Kabupaten Sigi.
\end{abstract}

Kata kunci: Ayam KUB, Budidaya, Motivasi, Rumah tangga, Usaha

Abstract

The BEKERJA program is an effort of the Ministry of Agriculture to alleviate poverty in the country based on agriculture with three stages, short, medium, and long term. In 2018, the Ministry of Agriculture is currently targeting the BEKERJA program to be implemented in 10 provinces, 776 villages and 200,000 Poor Households (RTM). Balitbangtan Superior Kampung Chicken or commonly known as KUB Chicken is one of the superior products in the livestock sector produced by the Agricultural Research and Development Agency (Balitbangtan). The advantages of KUB chicken compared to native chickens in general are that their growth is relatively faster, at the age of 70 days the KUB chickens can reach a weight of 800-1200 gr. Another advantage of KUB 
Prosiding Seminar Nasional Pembangunan dan Pendidikan Vokasi Pertanian Politeknik Pembangunan Pertanian Manokwari, 14 November 2020

e ISSN : 2774-1982

chickens is that egg production is above average, that is, in one year it can produce 160-180 eggs. Because of these advantages, KUB chickens were introduced in areas that have the potential for developing native chickens in Indonesia, including in Central Sulawesi. In 2019, the Central Sulawesi Agricultural Technology Research Center (BPTP) disseminated this Balitbangtan product through the KUB chicken development program on a household scale to five villages totaling 100 households as the main implementer of KUB chicken development. Household motivation to implement activities here is defined as a condition that encourages action, namely developing KUB chicken farming with a specific goal. To find out the household motivation for KUB chicken cultivation in Sigi, this study was conducted. Data analysis was carried out through a content and depth approach in translating a social phenomenon using various methods of analysis; descriptive method is used to describe the economic and social conditions of the household; Breeder characteristics. Data analysis about farmer motivation towards KUB chicken cultivation using a Likert scale. (Rensis Likert in Hermawan, 2015). The results of a valid Likert scale are added up for each respondent, then the mean is sought as a score for the variable Knowledge, Attitudes and Motivation. Overall, it can be concluded that the level of household motivation in developing the KUB chicken farming business is $68 \%$ very eager and $32 \%$ wish. Economic and social conditions become the motivational background for households, while cultivation technology has no significant effect. The results of this study are expected to recommend the dissemination of KUB chicken innovation and increase the motivation and economy of the community in Sigi Regency.

Keywords: Chicken KUB, Cultivation, Motivation, Household, Business

\section{PENDAHULUAN}

Indonesia kaya akan sumberdaya genetik ayam asli dan ayam lokal yang hampir tersebar di seluruh wilayah, telah teridentifikasi sebanyak 39 breed ayam lokal Indonesia dengan berbagai ciri spesifik dan fungsinya (Sartika 2016). Kemudian hasil penelitian LIPI bekerjasama dengan ILRI diketahui bahwa Indonesia merupakan salah satu pusat domestikasi ayam di dunia (Sulandari et al., 2009) dan penyebaran ayam di dunia berasal dari Asia termasuk Indonesia.

Populasi ternak unggas secara nasional pada tahun 2019 dibandingkan dengan populasi pada tahun 2018 mengalami peningkatan, dengan rincian sebagai berikut: ayam buras 301 juta ekor (peningkatan 0,96 persen), ayam ras petelur 261,9 juta ekor (peningkatan 1,19 persen), ayam ras pedaging 3,1 miliar ekor (peningkatan 7,36 persen), itik 50,5 juta ekor (peningkatan 3,00 persen), dan itik manila 9,0 juta ekor (peningkatan 6,14 persen). Sementara untuk populasi aneka ternak pada tahun 2019 juga mengalami peningkatan jumlah populasi apabila dibandingkan dengan populasi pada tahun 2018 (statistik Dirjen Nak 2019).

Program BEKERJA merupakan upaya Kementan untuk mengentaskan kemiskinan di tanah air berbasis pertanian dengan tiga tahapan, jangka pendek, menengah, dan panjang. 
Prosiding Seminar Nasional Pembangunan dan Pendidikan Vokasi Pertanian Politeknik Pembangunan Pertanian Manokwari, 14 November 2020

e ISSN : 2774-1982

Pada tahun 2018 saat ini Kementan menargetkan program BEKERJA dapat dilaksanakan di 10 provinsi, 776 desa dan 200.000 Rumah Tangga Miskin (RTM). Ayam Kampung Unggul Balitbangtan atau biasa dikenal dengan Ayam KUB merupakan salah satu produk unggulan di sektor peternakan yang dihasilkan oleh Badan Penelitian dan Pengembangan Pertanian (Balitbangtan). Keunggulan Ayam KUB dibandingkan dengan ayam kampung pada umumnya adalah pertumbuhannya relatif lebih cepat, pada umur 70 hari ayam KUB mampu mencapai bobot 800-1200 gr. Selain itu, keunggulan lain dari ayam KUB adalah produksi telur di atas rata-rata yakni dalam satu tahun dapat memproduksi telur 160-180 butir. Karena keunggulannya inilah ayam KUB mulai diperkenalkan di daerah-daerah yang memiliki potensi pengembangan ayam kampung di Indonesia, termasuk di Sulawesi Tengah (Tike, 2016).

Pada tahun 2019 ini Balai Pengkajian Teknologi Pertanian (BPTP) Sulawesi Tengah melakukan diseminasi produk Balitbangtan ini melalui program pengembangan ayam KUB pada skala rumah tangga ke lima desa sebanyak 100 rumah tangga (20 rumah tangga tiap desa) program ini selain sebagai hilirisasi inovasi teknologi hasil juga sebagai upaya rekonsiliasi pasca bencana alam tahun 25 Saptember 2018 di kabupaten Sigi. Motivasi petani memelihara ayam KUB di kabupaten Sigi ini disebabkan oleh mereka telah memelihara ayam kampung secara turun temurun serta sebagai salah satu usaha pasca bencana di Kabupaten sigi pada tahun 2018. Dari latar belakang tersebut penulis tertarik untuk mengkaji Motivasi dalam usaha budidaya ayam KUB.

\section{METODE}

Lokasi kajian terdapat di Kabupaten Sigi khususnya di Kecamatan Sigi Biromaru sebagai daerah pengembangan ayam KUB pada kegiatan pendampingan pengembangan ayam KUB berbasis rumah tangga. sebanyak 25 orang dari penerima sebanyak 100 rumah tangga. Penentuan responden dilakukan secara acak sederhana. Wawancara dilakukan kepada masing-masing responden menggunakan kuesioner setelah melaksanakan pemeliharaan ayam KUB pada bulan Desember 2019 - Maret 2020.

Variabel yang diamati adalah karakter peternak, pengetahuan, sikap dan motivasi yang mengacu kepada teori sikap dan teori motivasi. Karakter rumah tangga meliputi umur dan tingkat pendidikan, lama usaha, jumlah kepemilikan ayam. Motivasi yang dimaksud dalam kajian ini adalah motivasi rumah tangga penerima kegiatan model pengembangan ayam KUB berbasis rumah tangga dalam mengembangkan usaha budidaya ayam KUB. Analisis data dilakukan melalui pendekatan isi dan kedalaman dalam menterjemahkan 
Prosiding Seminar Nasional Pembangunan dan Pendidikan Vokasi Pertanian Politeknik Pembangunan Pertanian Manokwari, 14 November 2020

e ISSN : 2774-1982

suatu fenomena sosial dengan berbagai metode analisis; metode deskriptif digunakan untuk menggambarkan kondisi ekonomi dan sosial Peternak; karakteristik Peternak. Analisis data tentang motivasi peternak terhadap budidaya ayam KUB menggunakan skala Likert (Hendayana R 2016). Hasil skala Likert yang valid dijumlah untuk masing-masing responden, kemudian dicari reratanya sebagai skor variabel Pengetahuan, Sikap dan Motivasi. Makna skor (Setuju/Ingin dalam 5 gradasi) didapatkan dengan cara membandingkan skor tersebut dengan nilai maksimal yang mungkin diperoleh dari masingmasing variabel. Pertanyaan pada setiap indikator dibagi menjadi 5 skor: $\mathrm{SI}=$ Sangat ingin, $\mathrm{I}=$ ingin, $\mathrm{RR}=$ ragu-ragu, $\mathrm{TI}=$ Tidak ingin, $\mathrm{STI}=$ sangat tidak ingin .

\section{HASIL DAN PEMBAHASAN}

\section{Gambaran Umum Wilayah}

Kecamatan Sigi Biromaru adalah salah satu wilayah yang terletak di Kabupaten Sigi, berbatasan langsung dengan Kota Palu serta merupakan ibu kota Kabupaten Sigi. Untuk menuju kecamatan tersebut dapat ditempuh dengan menggunakan kendaraan roda empat dan roda dua dengan waktu tempuh \pm 10 - 30 menit dari Kota Palu.

Secara administratif Kecamatan Sigi Biromaru memiliki batas-batas sebagai berikut:

Sebelah Utara : berbatasan dengan Kecamatan Palu Selatan

Sebelah Selatan : berbatasan dengan Kecamatan Tanam Bulava

Sebelah Timur : berbatasan dengan Kecamatan Dolo

Sebelah Barat : berbatasan dengan Kecamatan Palolo

Luas wilayah Kecamatan Sigi Biromaru 289,60 km², yang semua desanya dapat dijangkau oleh kendaraan roda empat. Topografi Berdasarkan elevasi, bahwa Kecamatan Sigi Biromaru pada umumnya terletak di daerah dataran (65\%), perbukitan (25\%), pegunungan (10\%) dan terletak pada ketinggian 22-257 meter diatas permukaan laut. Elevasi suatu tempat sangat mempengarui terhadap pertumbuhan ayam KUB, dalam hal ini berkaitan dengan sirkulai angin suatu daerah tersebut.

Iklim merupakan hal penting dalam berusahatani terutama untuk menentukan pola tanam dan jenis tanaman yang sesuai dengan kondisi iklim tersebut. Iklim suatu daerah dipengaruhi oleh curah hujan, suhu, angin, kelembaban, udara dan sinar matahari. Tipe iklim suatu daerah dapat ditentukan berdasarkan jumlah bulan basah, bulan lembab dan bulan kerin selama kurun waktu (tahun) tertentu. 
Prosiding Seminar Nasional Pembangunan dan Pendidikan Vokasi Pertanian Politeknik Pembangunan Pertanian Manokwari, 14 November 2020

e ISSN : 2774-1982

Iklim Kecamatan Sigi Biromaru berdasarkan klasifikasi Oldemen termasuk tipe iklim E4 dimana daerah ini tidak terdapat bulan basah dan terjadi 6-12 bulan kering berturut-turut. Curah hujan rata-rata tahunan sebesar 9771,2 mm dan curah hujan terkecil pada bulan Maret sebesar 37,6 m. Daerah ini pada umumnya kering, usaha pertanian sebagian besar bergantung pada adanya hujan. Rendahnya tingkat curah hujan merupakan faktor pembatas utama untuk memenuhi kebutuhan air rumah tangga apalagi untuk kebutuhan peternakan ayam. Potensi sumberdaya alam yang dimiliki oleh Kecamatan Sigi Biromaru mendukung untuk perkembangan ayam KUB, pada daerah tertentu diwilayah tersebut perlu dilaksanakan perlauan teknis yang khusus terutama untuk mensiasati kelembapan udara.

\section{Gambaran sosial ekonomi}

Kecamatan Sigi Biromaru secara administrasi terdiri dari 17 desa dan 1 Unit Permukiman Transmigran (UPT), dimana berdasarkan klasifikasinya yang termasuk dalam klasifikasi desa swasembada ada 15 desa, sedang 2 desa yang lain masih termasuk desa swakarsa. Jumlah penduduk Kecamatan Sigi Biromaru pada tahun 2019 sebesar 46.274 dengan jumlah rumah tangga sebanyak 10.798 rumah tangga, sehingga rata - rata rumah tangga memiliki 3 - 4 anggota rumah tangga. Jumlah penduduk laki-laki berjumlah 23.568 jiwa dan penduduk perempuan 22.706 jiwa. Desa yang memiliki jumlah penduduk terbanyak adalah desa kalukubula yaitu 10.216 jiwa, sementara yang paling sedikit penduduknya adalah Desa Sidondo II yaitu sebanyak 831 jiwa. Bila dilihat dari kepadatan penduduknya, kepadatan penduduk rata rata di Kecamatan Sigi Biromaru adalah 157 jiwa/km2 . Desa yang paling padat penduduknya adalah Desa Kalukubula yaitu 1123 jiwa/km2. Sedangkan yang paling jarang penduduknya adalah UPT Lembah Palu hanya 33 jiwa/km2.

Berdasarkan kewarganegaraannya, penduduk di Kecamatan Sigi Biromaru semua berkewarganegaraan Indonesia. Pendidikan merupakan proses peningkatan sumber daya manusia yang pada gilirannya upaya mencerdaskan kehidupan bangsa, maka pendidikan tidak dapat lepas dari akan merupakan modal investasi manusia bagikepentingan pembangunan nasional. Tersedianya data tentang pendidikan yang baik akan sangat membantu perencanaan yang dibuat menjadi lebih terarah pada sasaran yang diharapkan. Jumlah sekolah TK di Kecamatan Sigi Biromaru pada tahun 2019 ada sebanyak 30 sekolah. Sekolah Dasar berjumlah 41 tersebar disemua desa, dimana desa yang paling banyak jumlah sekolahnya adalah Sidondo I, Maranata, Pombewe, Mpanau dan Kalukubula masing-masing 4 SD. Sedangkan SLTP ada 17 sekolah dan SLTA ada 9 sekolah yang 
Prosiding Seminar Nasional Pembangunan dan Pendidikan Vokasi Pertanian

Politeknik Pembangunan Pertanian Manokwari, 14 November 2020

e ISSN : 2774-1982

terletak di Desa Sidondo I, Bora, Maranata, Sidera, Pombewe, Lolu, Ngatabaru, Mpanau dan Kalukubula.

Sektor pertanian merupakan tumpuan kehidupan perekonomian di Kecamatan Sigi Biromaru pada umumnya. Oleh sebab itu, pembanguanan di sektor pertanian masih merupakan hal yang penting dalam mendukung pembangunan ekonomi sektor lainnya. Pembangunan pada sektor peternakan diupayakan untuk meningkatkan populasi dan produksi ternak. Ternak besar yang diusahakan di Kecamatan Sigi Biromaru sapi dan kambing. Ada sebanyak 6840 ekor ternak sapi, dimana ternak terbanyak terdapat di desa Kalukubula yaitu 858 ekor ternak. Ternak kecil yang diusahakan kambing, domba, dan babi. Pada ternak ayam ras 160,637 ekor pada ayam buras 24,399 ekor.

\section{Gambaran Potensi Perunggasan di Kabupaten Sigi}

Komoditas unggas mempunyai prospek pasar yang sangat baik karena didukung oleh karakteristik produk unggas yang dapat diterima oleh masyarakat Indonesia yang sebagian besar muslim, harga relatif murah dengan akses yang mudah diperoleh karena sudah merupakan barang publik. Komoditas ini merupakan pendorong utama penyediaan protein hewani nasional, sehingga prospek yang sudah bagus ini harus dimanfaatkan untuk memberdayakan peternak di perdesaan melalui pemanfaatan sumberdaya secara lebih optimal. Populasi ternak Kabupaten Sigi terdiri dari enam jenis ternak yaitu sapi kerbau, kuda, kambing, domba, dan babi. Populasi ternak terbesar Tahun 2019 masih didominasi oleh sapi sebesar 29.289 ekor, dimana jumlah terbesar berada di Kecamatan Sigi Biromaru sebanyak 6.840 ekor. Sedangkan Populasi unggas didominasi oleh ayam broiler/pedaging dengan total populasi 442.000 ekor, pada Tahun 2019. Lain halnya dengan ternak sapi, jumlah ayam kampung terbesar berada di Kecamatan Marawola sebesar 185.000 ekor

Potensi Kabupaten Sigi dalam sektor perunggasan didukung dengan luas lahan yang dan jumlah penduduk. Pada data statistik menunjukan kepadatan penduduk rata rata di Kecamatan Sigi Biromaru adalah 157 jiwa/km2. Sehingga dari segi aspek teknis perkandangan masih sangat potensial. Serapan pasar dari sektor perunggasan sangat tinggi dikarenakan Kabupeten Sigi merupakan satu-satunya Kabupeten di Propinsi Sulawesi Tengah yang tidak mempunyai laut. Sehingga pemenuhan gizi dari ayam yang mempunyai harga relatif terjangkau oleh masyarakat. Pada usaha ayam kampung masyarakat sudah melakukan secara turun temurun dari nenek moyang, sehingga dalam mendesiminasikan teknologi budidaya tidak mengalami kesulitan. Permintaan pengepul ayam kampung khususnya di Kabupaten Sigi adalah bobot badan 800 gram per ekor yang ditujukan untuk kuliner Ayam Panggang Biromaru, Ayam Panggang Biromaru disajikan dengan kuah 
Prosiding Seminar Nasional Pembangunan dan Pendidikan Vokasi Pertanian

Politeknik Pembangunan Pertanian Manokwari, 14 November 2020

e ISSN : 2774-1982

santan dalam bahasa daerah setempat uta dada dan ketupat adalah salah satu kuliner ayam kampung yang berasal dari Kabupaten Sigi, hal ini dapat menjadi peluang pasar pengembangan ayam KUB.

\section{Budidaya Ayam Kampung Unggul Balitbangtan}

Tike, et al. (2016), mengatakan Sebagai tindak lanjut pemanfaatan SDG ayam lokal Indonesia adalah berkembangnya industri nasional ayam lokal, yang akan menuntut berbagai penemuan ilmu pengetahuan dan teknologi berbasis sumberdaya genetikayam lokal. Sifat sifat kualitatif ayam KUB -1 sama dengan ayam kampung pada umumnya yang mempunyai warna bulu bervariasi. Keunggulan ayam KUB dapat dijadikan sebagai bibit galur betina merupakan bibit parent stock yang dapat dikawinkan dengan pejantan ayam lokal lainnya yang mempunyai bobot badan besar.

Usaha ayam kampung di Indonesia telah turun temurun dilaksanakan dengan model pemeliharaan yang ektensif. Pada tahun 2013 telah diluncurkan ayam kampung Badan Litbang Pertanian sebagai penghasil produk unggulan pertanian (termasuk ternak), melalui Balitnak yang telah melakukan penelitian dan menghasilkan produk-produk ternak unggul, seperti ayam KUB-1 dengan keunggulan produksi telur tinggi yaitu produksi telur henday $45-50 \%$, puncak produksi telur mencapai $84 \%$ pada umur ayam 31 minggu, bobot telur pertama bertelur $30 \mathrm{gr} / \mathrm{butir}$, dan akan bertambah terus sampai $36 \mathrm{gr} / \mathrm{butir}$ pada akhir bulan kedua berproduksi (Sartika eat al., 2015). Sementara itu, galur ayam Sensi-1 Agrinak yang merupakan singkatan dari "Sentul Terseleksi-1" merupakan salah satu galur murni (pure line) ayam lokal pedaging unggul, yang dapat dimanfaatkan sebagai ayam niaga (final stock) dan/ atau sebagai ayam tetua (parent stock). SenSi-1 Agrinak bulu abu abu dengan varian berwarna bulu abu abu dengan keseragaman $88 \%$; bentuk jengger kacang pada umur 70 hari; bobot tubuh anak umur satu hari (day old chick, doc) 29,7 g/ekor jantan betina; bobot tubuh umur 70 hari, jantan 1000 g/ekor, betina 800 g/ekor; feed conversion ratio (FCR) sampai umur 70 hari, FCR 2,7 - 3,7; bobot umur 20 minggu: jantan: 2381 kg/ekor; betina 1528 kg/ekor; sedangkan SenSi-1 Agrinak bulu Pucak (putih bercak hitam) dengan varian berwarna bulu pucak dengan keseragaman 95\%; bentuk jengger kacang pada umur 70 hari; bobot tubuh anak umur satu hari (day old chick, DOC) 30,5 g/ekor jantan betina; bobot tubuh umur 70 hari, jantan 1000 g/ekor, betina 800 g/ekor; feed conversion ratio (FCR) sampai umur 70 hari, FCR 2,7 - 3,7; bobot umur 20 minggu: jantan: 2424 kg/ekor; betina $1619 \mathrm{~kg} / \mathrm{ekor}$; dan relatif tahan terhadap penyakit (Iskandar, et al., 2016).

\section{Karakteristik Peternak}

Hasil identifikasi pada karakteristik individu responden 
Prosiding Seminar Nasional Pembangunan dan Pendidikan Vokasi Pertanian Politeknik Pembangunan Pertanian Manokwari, 14 November 2020

e ISSN : 2774-1982

\begin{tabular}{|c|c|c|c|c|}
\hline No & Karakteristik Internal & Kategori & $\begin{array}{l}\text { Jumlah } \\
\text { (Orang) }\end{array}$ & $\begin{array}{c}\text { Prosentase } \\
(\%)\end{array}$ \\
\hline \multirow[t]{3}{*}{1.} & \multirow[t]{3}{*}{ Umur } & Muda (20-35) & 8 & 32 \\
\hline & & Dewasa ( $36-45)$ & 10 & 40 \\
\hline & & Tua $(46-65)$ & 7 & 28 \\
\hline \multirow[t]{3}{*}{2} & \multirow[t]{3}{*}{ Pendidikan } & Rendah (Tidak tamat SD - SD) & 3 & 12 \\
\hline & & Sedang (SMP - SMA) & 21 & 84 \\
\hline & & Tinggi ( PT) & 1 & 4 \\
\hline \multirow[t]{3}{*}{3} & \multirow[t]{3}{*}{ Lama Usaha Ternak } & Rendah (<5 Tahun) & 7 & 28 \\
\hline & & Sedang ( 5 - 10 Tahun) & 10 & 40 \\
\hline & & Tinggi (> 10 Tahun) & 8 & 32 \\
\hline \multirow[t]{3}{*}{4} & \multirow{3}{*}{$\begin{array}{l}\text { Jumlah Kepemilikan } \\
\text { Ternak }\end{array}$} & Rendah ( <10 Ekor) & 13 & 52 \\
\hline & & Sedang $(10-20$ Ekor $)$ & 9 & 36 \\
\hline & & Tinggi (> 20 Ekor) & 3 & 12 \\
\hline
\end{tabular}

Responden $72 \%$ menunjukkan umur produktif yang memiliki kemampuan untuk bekerja dan menghasilkan sesuatu dalam mengelola sumber daya yang dimiliki serta dalam motivasi. Menurut Kotler dalam mohtar (2014) bahwa umur merupakan salah satu faktor dalam menentukan penilaian seseorang. hal ini sesuai dengan kenyataan di lapangan bahwa sebagian besar rumah tangga yang baik yang berumur tua maupun berumur muda cenderung memberikan motivasi yang positif terhadap motivasi serta inovasi teknologi Budidaya ayam KUB, karena ada kecenderungan mereka lebih antusias dengan sesuatu yang dianggap baru dan juga mempunyai kemauan untuk mendapatkan hasil ternaknya yang lebih tinggi dan motivasi untuk mendapatkan kesejahteraan yang lebih baik

Tingkat pendidikan formal yang ditempuh oleh responden SMP-SMA sebanyak 84 $\%$ ini berarti bahwa kualitas pendidikan responden dapat dibilang tinggi. Tingkat pendidikan biasanya menunjukan bahwa individu tersebut memiliki kemampuan untuk mencari, menerima dan menyerap inovasi untuk dapat merubah motivasi. Mohtar, 2004 mengatakan Pendidikan merupakan hal yang sangat penting dalam mempengaruhi pikiran seseorang. Seorang yang berpendidikan pada saat menemui suatu masalah akan berusaha difikirkan sebaik mungkin dalam menyelesaikan masalah tersebut. Melalui proses pendidikan yang melibatkan serangkaian aktivitas, maka seorang individu akan memperoleh pengetahuan, pemahaman, keahlian dan wawasan yang lebih baik melalui proses pendidikan yang melibatkan serangkaian aktivitas, maka seorang individu akan memperoleh pengetahuan, pemahaman, keahlian dan wawasan yang lebih baik termasuk dalam hal motivasi terhadap inovasi teknologi Budidaya ayam KUB. Hal ini sesuai dengan kondisi di lapangan bahwa sebagian besar peternak baik yang mempunyai latar pendidikan 
Prosiding Seminar Nasional Pembangunan dan Pendidikan Vokasi Pertanian Politeknik Pembangunan Pertanian Manokwari, 14 November 2020

e ISSN : 2774-1982

tinggi atau rendah, motivasinya cenderung positif terhadap motivasi untuk berbudidaya ayam KUB.

Lama berusaha dibidang peternakan khususnya ayam kampung $40 \%$ menunjukan sudah memelihara ayam kampung pada kategori sedang dan $32 \%$ pada kategori tinggi sudah diatas 10 tahun, bahkan lebih lama dikarenakan budidaya ayam kampung dilaksanakan secara turun temurun namun pemeliharaan masih bersifat tradisional ayam masih diumbar. Asumsi semakin lama berusaha, peternak akan banyak memperoleh pengalaman yang dapat diambil manfaatnya sehingga dapat membantu peternak dalam usahatani, serta motivasi dalam menerima sesuatu yang baru. Jumlah kepemilikan ternak 48\% tergolong sedang dan banyak dengan kepemilikan diatas 10 ekor. Dari hasil kajian pada karakter jumlah kepemilikan ternak, diketahui bahwa banyak atau sedikitnya jumlah penguasaan ternak yang diusahakan oleh peternak, diharapkan mampu merubah motivasi terhadap inovasi teknologi Budidaya budidaya ayam KUB.

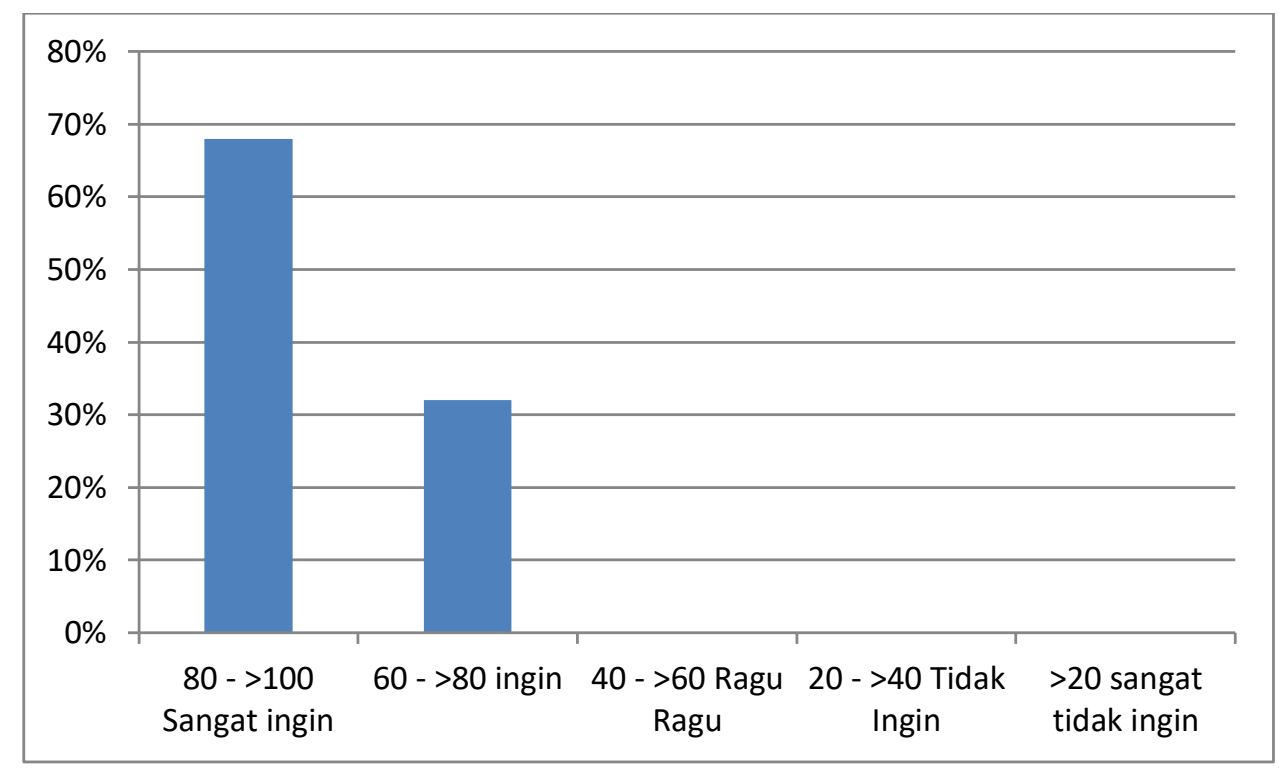

Grafik 1. Motivasi masyarakat terhadap budidaya ayam KUB

Berdasarkan Garafik 1 dapat diketahui bahwa motivasi petani terhadap budidaya ayam KUB kategori sangat ingin $68 \%$ dan ingin $32 \%$. Arti ini adalah budidaya ayam KUB merupakan ayam kampung yang baik sesuai dengan kebutuhan, responden beranggapan bahwa ayam KUB adalah ayam kampung yang terbaik. Hal ini dikarenakan mudah dalam pemeliharaan, tidak memerlukan keahlian dan pertumbuhan yang relatif cepat sehingga semakin meningkatkan motivasi untuk membudidayakan ayam KUB.

Keunggulan relatif (comparative advantage) atau jenis ayam KUB merupakan jenis ayam terbaik pada ayam kampung serta pertumbuhan yang lebih cepat, Suatu inovasi 
Prosiding Seminar Nasional Pembangunan dan Pendidikan Vokasi Pertanian

Politeknik Pembangunan Pertanian Manokwari, 14 November 2020

e ISSN : 2774-1982

dilihat dari suatu hal baru yang lebih baik dari yang pernah ada, dan memungkinkan bagi masyarakat mencapai tujuan dengan lebih baik atau dengan biaya yang lebih rendah daripada yang telah dilakukan sebelumnya diukur dari manfaat ekonomi, dan manfaat teknis dari segi prestise, dan kepuasan. Melalui penerapan inovasi, memungkinkan bagi petani meraih tujuannya dengan lebih baik atau biaya yang rendah. Sesuai pendapat Siregar (2006), masyarakat sebagai pengguna inovasi teknologi harus lebih selektif dalam memilih teknologi yang digunakan karena berkaitan dengan biaya yang dikeluarkan.

\section{KESIMPULAN DAN SARAN}

Motivasi rumah tangga terhadap Budidaya ayam KUB berada pada kriteria positif yang terbagi kategori ingin $32 \%$ kategori sangat ingin $68 \%$ baik dilihat dari ayam KUB merupakan jenis ayam kampung terbaik, mudah dalam pemeliharaan, tidak memerlukan keahlian khusus serta pertumbuhan relatif cepat. Motivasi yang baik dari responden menjadi modal untuk keberlanjutan kegiatan pengembangan ayam KUB skala rumah tangga. Secara umum motivasi rumah tangga terhadap Budidaya ayam KUB termasuk kategori baik, menunjukan bahwa usaha budidaya ayam KUb tersebut layak untuk dikembangkan serta disebarluaskan kepada rumah tangga lainnya melalui pendekatan kelompok. Untuk mencapai kesuksesan tersebut, sangat diperlukan suatu dorongan motivasi yang kuat dari dalam diri. Motivasi yang kuat bisa diambil dari kisah kesuksesan seseorang. Dengan kisah sukses seseorang, maka kita bisa mengambil pelajaran dengan motivasi penting yang dapat kita aplikasikan dalam kehidupan kita

\section{DAFTAR PUSTAKA}

Tike, R.S. (2016). Panen ayam Kampung 70 Hari, Penebar swadaya Jakarta.

Dirjen Peternakan dan Kesehatan Hewan Kementerian Pertanian. (2019). Satistik peternakan dan Kesehatan hewan 2019.

Rachmad Hendayana. (2006). Persepsi dan Adopsi Teknologi.

BPS. (2019). Kabupaten Sigi dalam Angka.

Sartika, T., Desmayati, S. Iskandar, H. Resnawati, A.R Setioko Sumanto, A.P Sinurat, \&Isbandi, B. Tresnamurti, \& E Romjali. (2013). Ayam KUB-I.

Narullah. (2017). Motivasi petani dalam pengembangan budidaya jagung kuning Studi Kasus Di Desa Marayoka, Kecamatan Bangkala, Kabupaten Jeneponto, Provinsi Sulawesi Selatan, Skripsi Universitas Hasanuddin.

Idin Saepudin Ruhimat. (2015). Tingkat Motivasi Petani Dalam penerapan Sistem Agroforestry, Balai Penelitian Teknologi Agroforestry. 